\title{
State Plan for Food and Nutrition Security: Potentialities and limitations
}

\author{
Plano Estadual de Segurança Alimentar e \\ Nutricional: potencialidades e limites
}

\author{
Mick Lennon MACHADO'1 (D) 0000-0001-7550-1692 \\ Cristine Garcia GABRIEL' ${ }^{1}$ iD 0000-0002-5413-0826 \\ Claudia SOAR ${ }^{2}$ iD 0000-0002-7079-2360 \\ Janaina das NEVES ${ }^{1}$ (D) 0000-0002-9026-9841 \\ Juliana Theodora Cunha de OLIVEIRA ${ }^{1}$ (iD) 0000-0003-4671-372X
}

\section{A B S T R A C T}

\section{Objective}

To identify potentialities and limitations for the execution of a State Plan for Food and Nutrition Security.

\section{Methods}

This is a qualitative research, using as a case the State Plan of Food and Nutrition Security of the state of Santa Catarina. The data were collected from an interview with eight key informants nominated by the executive secretaries of the Food and Nutrition Security Council and the Inter-Sectoral Food and the state Nutrition Security Board. The analysis took place through the Collective Subject Discourse method.

\section{Results}

The main potentialities were the quality of the plan and the structuring of the National System of Food and Nutrition Security in the state. The main limitations were related to the financial resources, to political interests and to the structure of the Management Chamber.

1 Universidade Federal de Santa Catarina, Centro de Ciências da Saúde, Programa de Pós-Graduação em Nutrição. Campus Universitário Reitor João David Ferreira Lima, s/n., Trindade, 88040-900, Florianópolis, SC, Brasil. Correspondência para/Correspondence to: CG GABRIEL. E-mail: <cristine.gabriel@ufsc.br>.

2 Universidade Federal de Santa Catarina, Centro de Ciências da Saúde, Departamento de Nutrição. Florianópolis, SC, Brasil.

Support: Ministério do Desenvolvimento Social, by the notice 01/2013.

Article based on the dissertation thesis of ML MACHADO, entitled: "Avaliação do Plano Estadual de Segurança Alimentar e Nutricional de Santa Catarina”. Universidade Federal de Santa Catarina, 2017.

Como citar este artigo/How to cite this article

Machado ML, Gabriel CG, Soar C, Neves J, Oliveira JTC. State Plan for Food and Nutrition Security: Potentialities and limitations. Rev Nutr. 2018;31(4):413-22. http://dx.doi.org/10.1590/1678-98652018000400006 


\section{Conclusion}

It is hoped that this study may support strategies that strengthen potentialities and minimize the limitations identified in the case studied, as well as in similar state contexts, contributing to the qualification of the Plans and consequent execution of the Food and Nutrition Security Policy.

Keywords: Evaluation. Food and nutrition security. Planning. Public policy.

\section{RE S U M O}

\section{Objetivo}

Este estudo teve como objetivo identificar potencialidades e limites para a execução de um Plano Estadual de Segurança Alimentar e Nutricional.

\section{Métodos}

Trata-se de uma pesquisa qualitativa, utilizando como caso o Plano Estadual de Segurança Alimentar e Nutricional de Santa Catarina. Os dados foram coletados a partir de entrevista com oito informantes-chave indicados pelas secretarias executivas do Conselho de Segurança Alimentar e Nutricional e da Câmara de Gestão Intersetorial de Segurança Alimentar e Nutricional do estado. A análise ocorreu por meio do método do Discurso de Sujeito Coletivo.

\section{Resultados}

As principais potencialidades apontadas foram a qualidade do Plano e a estruturação do Sistema Nacional de Segurança Alimentar e Nutricional no estado. Já as principais limitações estavam relacionadas aos recursos financeiros, interesse político e estrutura da Câmara de Gestão.

\section{Conclusão}

Espera-se que este estudo possa subsidiar estratégias tanto no caso estudado quanto em contextos estaduais similares, que fortaleçam as potencialidades e minimizem as limitações identificadas, contribuindo para a qualificação dos Planos e a consequente execução da Política de Segurança Alimentar e Nutricional.

Palavras-chave: Avaliação. Segurança Alimentar e Nutricional. Planejamento. Política Pública.

\section{INTROD U CTION}

Since 2006, Brazil has advanced to the construction of an intersectoral public policy that proposes to associate Food and Nutrition Security (FNS) with permanent strategies of economic and social development, in a background of increasing equity and social inclusion [1]. In this context, the Sistema Nacional de Segurança Alimentar e Nutricional (SISAN, National Food and Nutrition Security System) and the Politica Nacional de Segurança Alimentar e Nutricional (PNSAN, National Policy for Food and Nutrition Security) [2,3] were created.

From then on, states and cities have been encouraged to implement this Public Policy in their territories, and by 2014 all Brazilian states had already signed up to SISAN
[4]. At the three levels of government, the FNS Plans are the main planning, management and implementation tools of the PNSAN [2]. In addition to being prerequisites for joining SISAN, they are important because they define the multiannual intervention of public authorities for the promotion of FNS, and must respect proposals from the Conferências e dos Conselhos de Segurança Alimentar e Nutricional (CONSEA, Food and Nutrition Security Conferences and Councils) [5].

By the year 2017, 13 (48\%) of the 27 units of the federation had published their Plans [6]. However, in addition to publication, the proper implementation of such Plans is fundamental for this instrument to enable improvements in the food and nutrition security conditions of the Brazilian population. 
Considering the relevance of the evaluative studies for the qualification of public programs and policies [7], as well as the lack of research on SISAN, PNSAN and, mainly, FNS Plan. From a case study, this research identified potentialities and limitations for the execution of the first FNS Plan of the state of Santa Catarina (I FNS Plan-SC).

\section{E T HO D S}

This paper is a qualitative research, carried out through the case study of the I FNS Plan-SC, through interviews with key informants. The collection took place in 2016 through a semistructured script containing open questions that addressed the potentialities and limitations for the execution of the Plan.

The case was chosen for convenience. The state of Santa Catarina created its CONSEA in 2004 and the Câmara de Gestão Intersetorial de Segurança Alimentar e Nutricional (CAISAN, Intersectoral Food and Nutrition Security Board of Management) in 2011, which was the same year when the state joined SISAN. The state's first FNS Plan was published in 2014 and is valid until 2019 [8], being one of the few state plans legally in force during the study period [9].

For the interviews, key informants were chosen who, preferably, participated in the construction process of the Plan and were involved in the process of monitoring its execution. Considering that both CONSEA and CAISAN have attributions in the FNS Plan implementation process, the identification of the interviewees occurred after being indicating by the executive offices of the two instances of the state of Santa Catarina. Initially, 12 people were nominated, including representatives of the government and civil society, organized according to their interviewing priority, under the previously described inclusion criteria.

The interviews were conducted by the principal investigator and recorded using a digital voice recorder with recording capacity of up to 12 hours. As these interviews were being made, theoretical saturation was observed, where the data obtained began to show repetition, not adding new information and, thus, allowing the researcher to suspend the interviews [10]. Therefore, the final number of respondents was eight (67\%) people. In order to maintain anonymity, the interviewees were identified by codes (S1 to S8), not differentiating between representatives of the government and civil society, since the comparison between both groups was not the objective of the study.

The analysis was based on the methodology of the Discourse of the Collective Subject (DCS) [11]. The verbal statements were transcribed in verbatim and analyzed, selecting excerpts which expressed the speech content and forming the Key Expressions. From this, a brief description of their senses was associated with such contents, a stage that consisted in the construction of the Central Ideas. Subsequently, the statements of similar meaning were grouped into Central Ideas categories, and lastly in a single speech, thus forming the DCS [11]. The formation of DCS occurs on the basis of the most significant and convergent parts. Consequently, discourses that deviated to other directions and that would correspond to other Central Ideas were eliminated. Speeches that did not assume a collective character among those interviewed were also excluded.

The interviewees agreed to conduct the research, which was approved by the Committee of Ethics in Research with Human Beings of the Universidade Federal de Santa Catarina (UFSC, Federal University of Santa Catarina) (protocol $n^{\circ}$ $1.160,850 / 2015)$.

\section{RE S U L T S}

\section{Potentialities}

The interviewees indicated the quality of the plan and the structuring of the SISAN in the 
state as the main potentialities for implementing the I FNS Plan-SC (Figure 1).

Regarding the quality of the plan, three Central Ideas were identified. The first one referred to the "plan being constructed with possible goals to be executed", whose DCS states that:

I always thought of very broad and difficult goals. The technical assistance hired to prepare the Plan carried out the entire FNS diagnosis of the state and identified all FNS actions that the state had already carried out and that were present in the pluriannual plan. This allowed the plan to be more realistic and feasible to be executed (S1, S2, S4, S6, S7).

The second Central Ideas highlighted the "involvement of government sectors in the construction of the plan", expressed from the following DCS:

The construction of the plan involved a number of government offices and agencies, which led to the accountability of various sectors, which is important for the execution of the plan (S1, S2, S3, S4, S5, S7, S8).

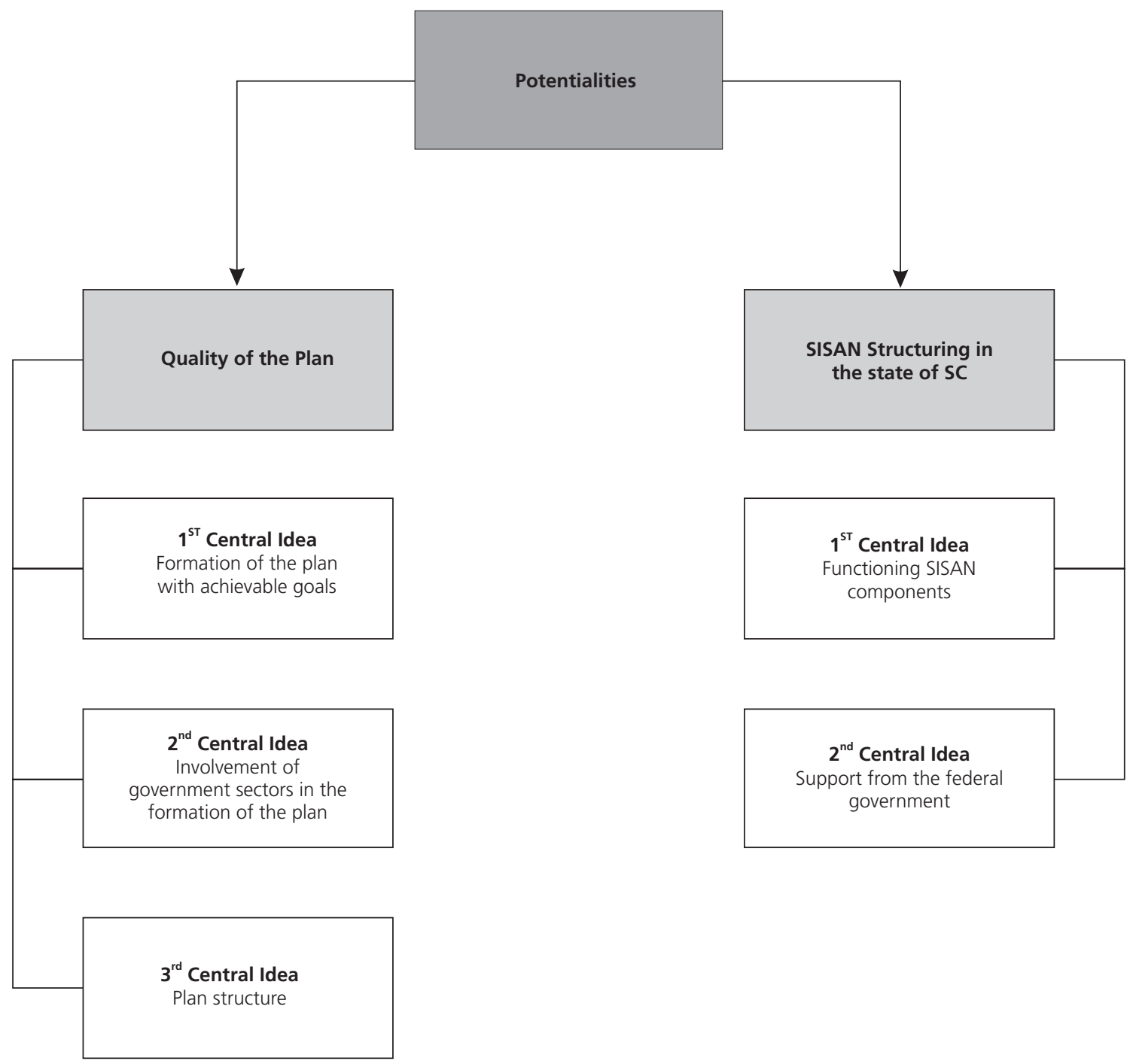

Figure 1. Potentialities for implementation of the I State Plan of Food and Nutrition Security of Santa Catarina (SC), Brazil, 2016. Note: SISAN: Sistema Nacional de Segurança Alimentar e Nutricional; SC: Santa Catarina. 
The last Central Ideas highlighted the "structure of the plan". The DCS related to this Central Ideas revealed that:

The plan is well detailed, with clear actions and about those who are accountable. I know what my responsibilities are and what I need to do (S2, S3, S4, S6).

About the structuring of a state SISAN plan, the interviews pointed two Central Ideas: "functioning components of SISAN" and "federal government support".

For the first Central Ideas, the following DCS was obtained:

The fact that the State has already had the CONSEA for a long time, to have an active CAISAN and to hold FNS Conferences with the proper involvement of the government and the civil society, increases pressure and the possibility of executing the plan (S1, S2, S4, S5, S6, S7, S8).

The second Central Ideas was expressed through the following DCS:
The federal government, particularly the Ministry of Development, the CAISAN and the National CONSEA has supported the state through financing that permits advisory services to be hired, as well as the implementation of training and the preparation of projects that aid in the proper execution of the plan (S1, S2, S3, S7, S8)

\section{Limitations}

The interviewees highlighted financial resources, political interest and the structure of CAISAN as limitations for the execution of the I FNS Plan-SC (Figure 2).

In relation to financial resources, two Central Ideas were listed. The first mentions the "non-existent linkages between budgetary planning and the actions of the plan", described from the DCS:

No action in the plan has an indication of its source of financial resources. I

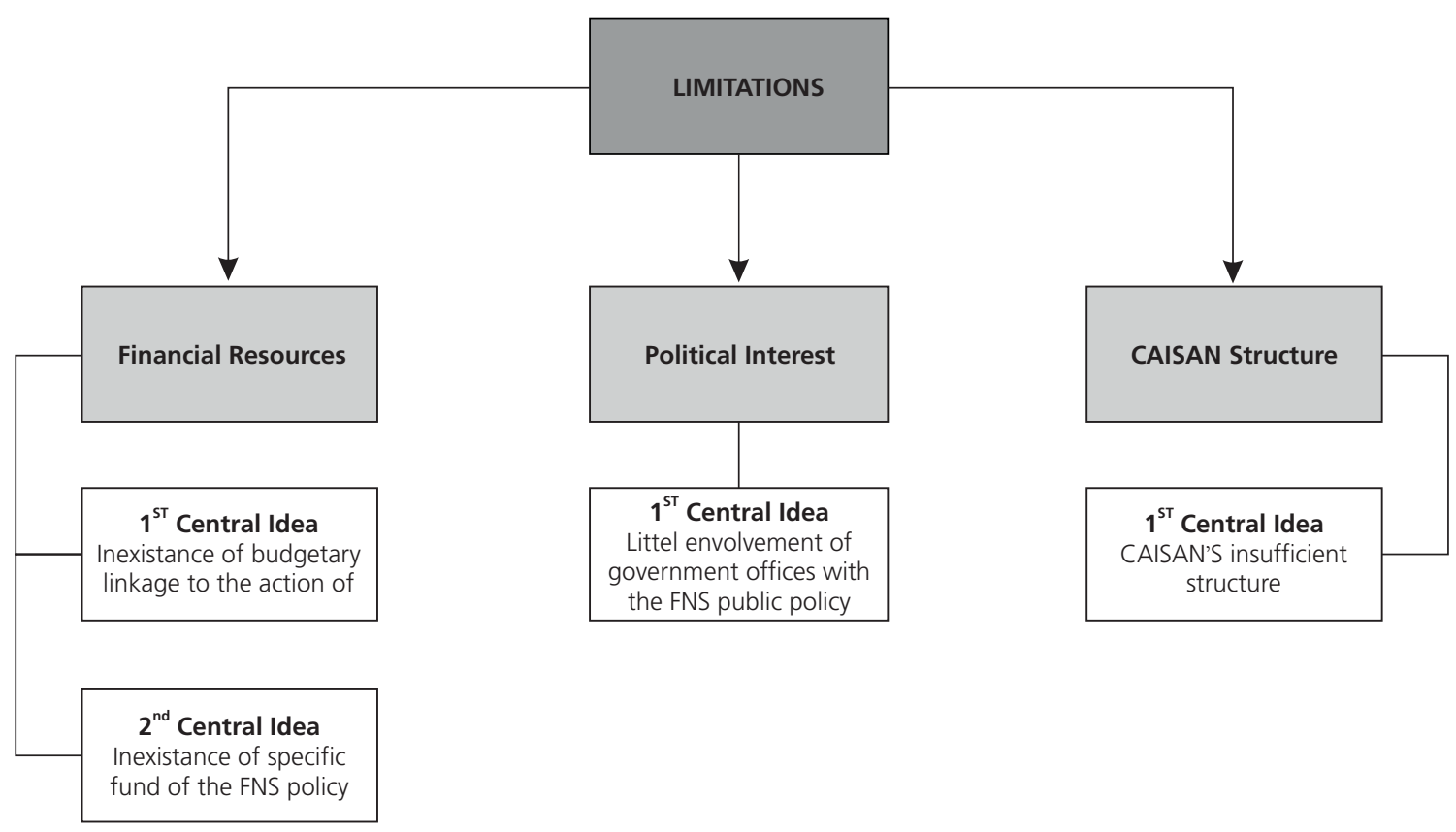

Figure 2. Limitations for implementation of the I State Plan of Food and Nutrition Security of Santa Catarina (SC) Brazil, 2016. Note: CAISAN: Câmara de Gestão Intersetorial de Segurança Alimentar e Nutricional; FNS: Food and Nutrition Security. 
try to include the actions of the Food and Nutrition Security Plan in the State Pluriannual Plan, but it is very difficult, because everyone competes for very little resources. Thus, there is no forecasted budget to perform the actions (S1, S2, S3, S4, S5, s7).

The other Central Ideas refers to the "inexistance of a specific fund for the FNS policy", whose DCS is:

Since there is no FNS policy fund, the actions foreseen in the FNS plan depend almost exclusively on state resources, which are already committed to sectoral public policies (S1, S4, S5, S6, S7, S8).

Political interest results in the Central Ideas "little involvement of government offices with the FNS public policy", and in DCS:

The FNS policy in the state is run by technicians who have no decision-making power. Whenever there is a need for involvement of government offices, there is a great lack of interest and no prioritization for this public policy. Perhaps because they believe that there are no starving people in the state ( $\mathbf{2}$, S3, S4, S5, S7).

Regarding the structure of CAISAN, the interviewees highlighted the Central Ideas "insufficient structure of CAISAN for its attributions", which is reflected in the following DCS:

CAISAN does not have enough personnel, resources and structure to ensure adequate follow-up of the implementation of the FNS Plan. Even though it is an intersectoral policy, no other government office deploys employees or allocates resources to CAISAN, leaving all responsibility to the Social Assistance, Labor and Housing Office (S1, S2, S3, S4, S6, S7).

\section{I S C U S S I O N}

The quality of the Plan and the structuring of a state SISAN plan were the identified potentialities by the interviewees.
Regarding the quality of the plan, the fact of it "being built with possible goals to be reached" was considered an important element for its execution. The adequate diagnosis of the situation and the FNS actions carried out by the state were characteristics which were present in the DCS. Fodd and Nutrition Security Plan should be elaborated from the proposals coming from the FNS Conferences; of a FNS diagnosis that identifies the main demands of the population and the territory; and the FNS-related targets set out in the Pluriannual Plan [1]. An appropriate process of collecting this information allows a more adequate planning to the local reality [12]. Also, the identification of actions already carried out by public managers and that can be incorporated into FNS Plan, makes it more feasible.

Diagnosing the situation of FNS is a challenge for SISAN. The multidimensionality of the Brazilian FNS concept requires a considerable number of macro, meso and micro-socioeconomic indicators [13], imposing the need to develop comprehensive and systemic information collection methodologies and tools [14], and information sources that are not always available or systematized.

The identification of conducted or planned actions, and which may comprise the FNS Plan, should occur, as a matter of priority, from the analysis of the local Pluriannual Plan. The organization of government actions in the Pluriannual Plans is mandatory $[15,16]$, a management tool designed to organize and enable public action, defining the set of government policies, as well as the budget and resources needed to achieve these goals [17]. By using the Pluriannual Plan as a source of information for the construction of the FNS Plan, the possibility of executing the Plan is increased, mainly due to the existence of budgetary forecasts for the goals.

Such is the importance of linking FNS Plan to the Pluriannual Plan as a way of ensuring budget for the goals, which according to the DCS 
of key informants regarding financial resources, the inexistence of budgetary linkage to the actions of the plan appears as an important limitation for its execution. It is observed that this is a reality for more than $60 \%$ of state FNS Plans, which do not describe or only partially define the source of financial resources for the implementation of the proposed goals [6].

This finding points to an important contradiction in the results found, for at the same time that the quality of the Plan is chosen as a potentiality, its inability to be a part of the agenda on public accounts appears as an important limitation. Understanding public accounts as a technical, but also a political, tool highlights the role of institutional actors involved in power disputes that tend to influence the possibilities of allocation and application of resources in the various public policies [18]. Thus, in the context of the PNSAN, even though CONSEA does not have a deliberative character or enforcement of resources [2], its directors must take actions that convert the public budget as a way to promote an effective insertion of the theme of food and nutritional security in the public policy agenda.

Further as regards to financial resources, the budgetary guarantee from the Pluriannual Plan becomes necessary vis-a-vis the DCS which points out that there is no specific fund for the FNS policy as a limitation for the implementation of the FNS Plans. National Food and Nutrition Security System provides for the management pact, as well as bipartite and tripartite forums [1] as mechanisms to secure financing of FNS actions in a stable manner, from financial resources of both the Ministry of Health and of the State and Municipal Health Offices, similar to what occurs in other systems $[19,20]$. However, these mechanisms are still not regulated and do not exist in fact. Even in the face of this fragility, respondents indicate that the support of the federal government, achieved through the structuring of SISAN in the state, has ensured the achievement of goals, either through financing or through the development of actions that respond to the demands of the state.

Another point highlighted as a potentiality and referring to the quality of the plan was the involvement of government sectors in the construction of the Plan, reinforcing the importance of intersectoriality as an inherent aspect of SISAN [21,22]. In the process of construction of the plan, the presence of several government offices was perceived as a positive factor for promoting co-responsibility. In this sense, it is emphasized that the diagnosis of demands and definition of strategies depend on the view of several sectors of the society and the government $[19,20]$. In the state of Santa Catarina, the plan was built with the participation of nine offices which were components of CAISAN, five invited public agencies, four collaborating institutions and a technical consultant who was responsible for conducting and systematizing the process [8]

"CAISAN's insufficient structure" for its attributions was identified as a limitation. It is intended that PNSAN, at all levels of government, be administratively linked to the chief executive's office as a strategy to enhance intersectoriality. However, the reality found is quite different, with $78 \%$ of states allocating PNSAN coordination in human rights, citizenship, social assistance and affirmative policies government offices [9], which may be justified considering the sectoral organization of the public sector and the historical difficulty of dialogue and intersection of actions between public policies. Moreover, the fact that these offices generally take responsibility for social rights councils and the historical association of FNS, based only on their dimension of access to sufficient quantities of food, [23] can also explain the sectorization of FNS's food policy management.

Understanding of the PNSAN as a public policy that responds mainly to the dimension related to the fight against hunger was also exposed in the $\mathrm{Cl}$ "little involvement of government secretaries with the FNS public 
policy". Another element that may justify the disinterest of government secretaries and the head of executive power is the decentralization of public policies [24]. On the federative state, it is presumed that the entities linked to the union will start to create and strengthen policies derived from fiscal decentralization.

However, reality shows that public managers tend to non-adherence if they believe that adherence to the public policy will result in a burden greater than the financial or political benefits [25]. Thus, in the context of a system which did not regulate its management pact, its bipartite and tripartite forums, and the creation of a specific fund for decentralizing resources, it is understandable how difficult it is to raise managers' awareness to create enough structural conditions to ensure proper implementation of FNS Plans.

Even in the face of these limitations, the interviewees stated that the structuring of a state SISAN plan, with its "functioning components", has facilitated the execution of the Plan. The CONSEA has the role of articulating, monitoring and following up on the implementation of the Plans, while CAISAN is responsible for the elaboration, coordination, execution and monitoring [2]. Despite the importance of these instances for the implementation of FNS Plan, less than half of the Brazilian states provide financial resources for their CAISAN [9], exposing a challenging scenario to ensure the functioning of the components within the System.

Respondents stated that the structure of the plan, with defined goals and a detailed description of those who are responsible for each goal, is a potential for implementation. The SISAN regulations define the need to clarify the responsibilities of SISAN agencies and entities to achieve those goals [2]. The definition of the responsible for each goal, besides allowing an adequate monitoring of the execution of the plan, also allows for a greater involvement of the sectors with the Plan by imposing duties in order to achieve these goals [26]. In planning, one of the most relevant aspects is the clarity of those who are involved in relation to their responsibilities, the stages and deadlines to be met, and how often they will render account for their duties [27].

\section{CONCLUSION}

This research identified the DCS of government representatives and civil society on the potentialities and limitations for execution of the I FNS Plan of the state of Santa Catarina. The quality of the plan and the structuring of a state SISAN plan were referred to as the main potentialities. As for the financial resources, political interest and the structure of CAISAN were the main limitations pointed out.

These results indicate characteristics that must be worked out by the managers of the FNS State Policy, as a way of ensuring that the Plan is executed and, consequently, enables the transformation of the reality of FNS in the state.

Although the results are limited to the reality of the state of Santa Catarina, it is understood that the potentials and limitations described reflect a situation that is part of the national context of SISAN and PNSAN. It is hoped that this study will stimulate further research evaluating aspects of SISAN management, in an attempt to improve this policy and, consequently, to improve the FNS situation and to ensure the human right to adequate food.

\section{CONTRIBUTORS}

ML MACHADO contributed in the conception, design, analysis and data interpretation. CG GABRIEL contributed in the conception and research design. All authors participate of the final review and approval of the article.

\section{REFERE NCES}

1. Bandoni DH, Marchioni DML, Brasil BG, Figueiredo IC, Sarti FM. O programa de incentivo à instalação 
de cozinhas comunitárias: avaliação de uma política pública brasileira. Nutrire. 2010;35(1):15-27.

2. Ministério do Desenvolvimento Social e Combate à Fome (Brasil). Decreto $n^{\circ} 7.272$, de 25 de agosto de 2010. Regulamenta a Lei $n^{\circ} 11.346$, de 15 de setembro de 2006, que cria o Sistema Nacional de Segurança Alimentar e Nutricional SISAN com vistas a assegurar o Direito Humano à Alimentação Adequada, institui a Política Nacional de Segurança Alimentar e Nutricional - PNSAN, estabelece os parâmetros para a elaboração do Plano Nacional de Segurança Alimentar e Nutricional, e dá outras providências. Brasília: Ministério do Desenvolvimento Social; 2010

3. Ministério do Desenvolvimento Social e Combate à Fome (Brasil). Lei $n^{\circ} 11.346$, de 15 de setembro de 2006. Cria o Sistema Nacional de Segurança Alimentar e Nutricional - SISAN com vistas em assegurar o direito humano à alimentação adequada e dá outras providências. Brasília: Ministério do Desenvolvimento Social; 2006.

4. Machado ML, Gabriel CG, Soar C, Mamed GR, Machado PMO, Lacerda JT, et al. Adequação normativa dos Planos Estaduais de Segurança Alimentar e Nutricional no Brasil. Cad Saúde Pública. 2018;34(1):e00206716. http://dx.doi.org/10.15 90/0102-311X00206716

5. Rigon SDA, Schmidt ST, Bógus CM. Desafios da nutrição no Sistema Único de Saúde para construção da interface entre a saúde e a segurança alimentar e nutricional. Cad Saúde Pública. 2016;32(3):e00164514. http://dx.doi. org/10.1590/0102-311X00164514

6. Câmara Interministerial de Segurança Alimentar e Nutricional. Caisan Estadual: Planos Estaduais. [acesso 2017 set 25]. Disponível em: http://mds.gov. br/caisan-mds/caisan-estadual/planos-estaduais-1

7. Samico I, Felisberto $E$, Figueiró AC, Frias PG. Avaliação em saúde: bases conceituais e operacionais. Rio de Janeiro: MedBook; 2010.

8. Câmara Interministerial de Segurança Alimentar e Nutricional. Plano Estadual de Segurança Alimentar e Nutricional: Santa Catarina 20142019. Florianópolis: Governo de Santa Catarina; 2014.

9. Câmara Interministerial de Segurança Alimentar e Nutricional. MapaSAN. Brasília: Ministério do Desenvolvimento Social, 2017 [acesso 2017 ago 25]. Disponível em: https://aplicacoes.mds.gov.br/ sagi/portal/pesquisa. php?valor=\%20mapasan

10. Fontanella BJB, Luchesi BM, Saidel MGB, Ricas J, Turato ER, Melo DG. Amostragem em pesquisas qualitativas: proposta de procedimentos para constatar saturação teórica. Cad Saúde Pública.
2011;27(2):388-94. http://dx.doi.org/10.1590/S01 02-311X2011000200020

11. Lefevre F, Lefevre AMC, Teixeira, JJV. O discurso do sujeito coletivo: uma nova abordagem metodológica em pesquisa qualitativa. Caxias do Sul: EDUCS; 2000.

12. Gondim GMDM, Monken M, Rojas LI, Barcellos C, Peiter P, Navarro MBMA, et al. O território da saúde: a organização do sistema de saúde e a territorialização. Rio de Janeiro: Fiocruz; 2013.

13. Kepple AW, Segall-Corrêa AM. Conceituando e medindo segurança alimentar e nutricional. Ciênc Saúde Coletiva. 2011;16(1):187-99. http://dx.doi. org/10.1590/S1413-81232011000100022

14. Azevedo ED, Ribas MTGDO. Estamos seguros? Reflexões sobre indicadores de avaliação da segurança alimentar e nutricional. Rev Nutr. 2016;29(2):241-51. http://dx.doi.org/10.1590/16 78-98652016000200008

15. Constituição da República Federativa do Brasil. Brasília: Senado Federal; 1988.

16. Presidência da República (Brasil). Decreto $n^{\circ}$ 2.829, de 29 de outubro de 1998. Estabelece normas para a elaboração e execução do Plano Plurianual e dos Orçamentos da União, e dá outras providências. Brasília: Diário Oficial da União; 1998.

17. Cavalcante P. O Plano Plurianual: resultados da mais recente reforma do Planejamento e Orçamento no Brasil. Rev Serv Público. 2014;58(2):129-50.

18. Abreu CR, Câmara LM. O orçamento público como instrumento de ação governamental: uma análise de suas redefinições no contexto da formulação de políticas públicas de infraestrutura. Rev Adm Pública. 2015;49(1):73-90. http://dx.doi. org/10.1590/0034-76121776

19. Rocha NC, Doria NG, Boia JM, Bógus CM. Organization and dynamics of Conselho Municipal de Segurança Alimentar e Nutricional de São Paulo: Implications of their participation on the creation of a municipal food and nutrition security policy. Rev Nutr. 2012;25(1):133-46. http://dx.doi. org/10.1590/S1415-52732012000100012

20. Monnerat GL, Souza RG. Política social e intersetorialidade: consensos teóricos e desafios práticos. Rev Ser Social. 2010;12(26):200-20.

21. Burlandy L. A construção da política de segurança alimentar e nutricional no Brasil: estratégias e desafios para a promoção da intersetorialidade no âmbito federal de governo. Ciênc Saúde Coletiva. 2009;14(3):851-60. http://dx.doi.org/10.1590/S14 $13-81232009000300020$ 
22. Burlandy L. Segurança alimentar e nutricional: intersetorialidade e as ações de nutrição. Saúde Rev. 2004;6(13):9-15.

23. Marques RMM, Mendes Á. Os dilemas do financiamento do SUS no interior da seguridade social. Econ Soc. 2016;14(1):159-75.

24. Salvador E. Fundo Público e o financiamento das Políticas Sociais no Brasil. Serv Soc Rev. 2012;14(2):4-22.

25. Vaitsman J, Andrade GRBD, Farias LO. Proteção social no Brasil: o que mudou na assistência social após a Constituição de 1988. Ciênc Saúde
Coletiva. 2009;14(3):731-41. http://dx.doi.org/10. 1590/S1413-81232009000300009

26. Arretche M. Relações federativas nas políticas sociais. Educ Soc. 2002;23(80):24-48. http://dx. doi. org/10.1590/S0101-73302002008000003

27. Arretche M. Políticas sociais no Brasil: descentralização em um Estado federativo. Rev Bras Ciênc Soc. 1999;14(40):111-41. http://dx.doi.org/10. 1590/S0102-69091999000200009

Received: September 11, 2017

Final version: July 6, 2018

Approved: August 14, 2018 